\title{
Performance of Wheat as Affected by Different Irrigation Levels and Sowing Dates
}

\author{
Md. Sohel Mahmud ${ }^{1}$, Md. Jafar Ullah ${ }^{1}$, Md. Abdullahil Baque ${ }^{1}$, Lutfun Naher ${ }^{1}$ \\ and Sayed Mohammad Mohsin ${ }^{2}$ \\ ${ }^{1}$ Department of Agronomy, ${ }^{2}$ Department of Plant Pathology, Sher-e-Bangla Agricultural University, \\ Dhaka-1207, Bangladesh
}

*Corresponding author and Email: sohelsau07@gmail.com

Received: 20 Oct 2016

Accepted: 12 December 2016

\begin{abstract}
The experiment was conducted to determine the effect of irrigations and sowing dates on growth and yield performance of wheat in the experimental field of Sher-e-Bangla Agricultural University, Dhaka, Bangladesh during the period of November 18, 2012 to March 30, 2013. The experiment was comprised of two factors, viz. factor A: two irrigations namely irrigation (I) and no irrigation i.e. control $\left(\mathrm{I}_{0}\right)$, and factor $\mathrm{B}$ : three sowing dates such as $\mathrm{S}_{1}: 1^{\text {st }}$ sowing on 18 November, $\mathrm{S}_{2}$ : $2^{\text {nd }}$ sowing on 03 December and $S_{3}: 3^{\text {rd }}$ sowing on 18 December. The experiment was laid out in a split plot design with three replications. Irrigation was assigned in the main plot, while sowing time was in the subplots. Data on grain yield and different yield contributing characters were taken after harvest. Results indicated that the highest grain yield was obtained with I $\left(2.915 \mathrm{t} \mathrm{ha}^{-1}\right)$ and $\mathrm{S}_{1}\left(2.983 \mathrm{t} \mathrm{ha}^{-1}\right)$. The interaction of irrigation (I) and sowing on 18 November $\left(\mathrm{S}_{1}\right)$ showed the maximum yield $\left(3.387 \mathrm{t} \mathrm{ha}^{-1}\right)$, spike length $(17.08 \mathrm{~cm}), 1000$ grain weight $(43.4 \mathrm{~g})$, spikelets spike ${ }^{-1}(20.03)$ and grain spike ${ }^{-1}(65.58)$ of wheat.
\end{abstract}

Keywords: CRI, Moisture, Spike, Spikelet, Harvest index.

\section{Introduction}

Wheat (Triticum aestivum L.) is primarily grown across the exceptionally diverse range of environments. It is an important cereal crop and mainly consumed as staple food in the world (Khan et al., 2007). High yield production of wheat is needed to feed the growing population of the world (Khakwani et al., 2012). Selection of proper sowing date is vital to obtain high yield due to variation among the weather conditions (Murungu and Madanzi, 2010). Proper sowing date and irrigation could be responsible for high crop production. Wheat is grown in winter season. Too early sowing, when temperature will be above then the optimum could also produce poor plants. At optimum temperature, early sowing enhances the wheat growth and nutrient uptake. Whereas delay in crop sowing cause reduction in yield (Yajam and Madani, 2013). But the largest area of wheat cultivation in the warmer climates exists in the South-East Asia including Bangladesh, India and Nepal (Dubin and Ginkel, 1991). Generally wheat supplies carbohydrate $(69.60 \%)$ and reasonable amount of protein $(12 \%)$, fat $(1.72 \%)$, and also minerals $(16.20 \%)$ and other necessary nutrients (BARI, 1997). 
Wheat cultivation has increased manifolds to meet up the food shortage in the country. Despite its enormous importance, the yield of the crop in Bangladesh is rather low $\left(2.2 \mathrm{t} \mathrm{ha}^{-1}\right)$ in comparison to other countries of the world, such as Japan, France, Germany and UK, where the yield levels are 3.76, and 7.12, 7.28, and 8.00 tha $^{-1}$, respectively (FAO, 2000). At present about 706.33 thousand hectares of land in Bangladesh is covered by wheat with the annual production of 1,592 thousand tons (BBS, 2011). The low yield of wheat in Bangladesh however is not an indication of low yield potentiality of this crop, but may be attributed to a number of reasons viz. unavailability of quality seeds of high yielding varieties, delayed sowing after the harvest of transplanted aman rice, fertilizer management, disease and insect infestation and improper or limited irrigation facilities. Among different factors, irrigation facilities with sowing time of wheat are the major reasons of yield reduction in Bangladesh. In Bangladesh, wheat is grown during Rabi (winter) season when it is dry and the inadequate soil moisture during the season limits the use of fertilizers, and consequently results in decreased grain yield. About $42.78 \%$ of the total wheat area in the country is irrigated and the rest is cultivated under rainfed condition (BBS, 2008). Irrigation plays a vital role in terms of bringing good growth and development of wheat. Insufficient soil moisture affects both the germination of seed and uptake of nutrients from the soil. Irrigation frequency also has a significant influence on growth and yield of wheat (Khajanij and Swivedi, 1988).

Generally, wheat is sown in November to ensure optimal crop growth and avoid high temperature at the terminal growth stage. After that if wheat is sown in the field then it faces high range of temperature. Among different factors, late sowing of wheat is one of the major reasons of yield reduction, because about $60 \%$ of the wheat is cultivated in late sowing conditions after harvesting of the transplanted aman rice (Badaruddin et al., 1994). Temperature is one of the major environmental factors that govern grain yields in wheat significantly.
Photosynthesis in wheat is maximum between 22 and $25^{\circ} \mathrm{C}$ and decreases sharply above $35^{\circ} \mathrm{C}$ (AlKhatib and Paulsen, 1990). Late planted wheat plants face a period of high temperature stress during reproductive stages causing reduced kernel number spike ${ }^{-1}$ (Islam et al., 1993) and reduced kernel weight (Acevedo et al., 1991) as well as the reduction of seed yield (Islam et al., 1993). The present study was therefore undertaken to determine the effect of irrigation and optimum sowing time on the growth and yield performance wheat.

\section{Materials and Methods}

The experiment was conducted in the Agronomy Field, Sher-e-Bangla Agricultural University (SAU), Dhaka-1207 during the period of November 18, 2012 to March 30, 2013.The experimental field was located at $23^{\circ} 41^{\prime} \mathrm{N}$ latitude and $90^{\circ} 22^{\prime} \mathrm{E}$ longitude at a height of $8.6 \mathrm{~m}$ above the sea level belonging to the Agroecological Zone "AEZ-28" of Madhupur Tract (BBS, 2011). The soil of the research field was slightly acidic having $\mathrm{p}^{\mathrm{H}} 5.8$ in reaction with low organic matter content $(0.78 \%)$. The experimental field was situated under subtropical climate; usually the rainfall is heavy during kharif season, (April to September) and scanty in rabi season (October to March). The experiment was consisted of two factors as irrigations and sowing dates. Factor $\mathrm{A}$ : $\mathrm{I}_{0}=\mathrm{No}$ irrigation and $\mathrm{I}=$ Irrigation (three irrigations were applied; the first irrigation was after 20 days of sowing at crown root initiation (CRI), the second after 45 days and the third irrigation after 62 days). Factor B: $S_{1}=1^{\text {st }}$ sowing on 18 November, 2012, $S_{2}=2^{\text {nd }}$ sowing on 03 December 2012) and $S_{3}=3^{\text {rd }}$ sowing on 18 December 2012.

Ploughing was followed by laddering in order to break clods as well as level the land. The experiment was laid out in a split plot design with three replications. Land was prepared by applying proper doses of manures and fertilizers which was recommended by BARI for wheat cultivation. Urea-220 kg ha' ${ }^{-1}$, TSP-180 kg ha-1, 
MoP-50 kg ha ${ }^{-1}$ and Gypsum-120 kg ha ${ }^{-1}$ were applied. Total urea was split twice being the first dose was applied at sowing time and second dose at 21 DAS (CRI). The whole amounts of triple super phosphate, muriate of potash and gypsum were incorporated in each plot at the time of final land preparation.

BARI Gom-21 (Shatabdi) was used as a test crop in the study. Before sowing, seeds were treated with Provax 200WP @ $2.5 \mathrm{~g} \mathrm{~kg}^{-1}$ seed. Seeds were sown continuously in line@ $120 \mathrm{~kg} \mathrm{ha}^{-1}$. The line to line distance was maintained $20 \mathrm{~cm}$. Before sowing a light irrigation was done for uniform seed germination and after sowing, the seeds were covered with soil and lightly pressed by hand. Intercultural operations were done to ensure normal growth of the crop. Weeding was done twice during the whole growing period. The crops were sprayed at 35 days with Malataf (Malathion 57EC) @ 2ml/L to control the insects and diseases.

The crop was harvested at different dates on the basis of sowing time. $1^{\text {st }}$ sowing was harvested 12 March 2013, $2^{\text {nd }}$ sowing was harvested 24 March 2013 and $3^{\text {rd }}$ sowing was harvested 30 March 2013. The selected sample plants were then harvested, bundled, tagged and carefully carried to the threshing floor in order to collect the data. For recording yield components data, ten hills from each plot were collected randomly. Threshing, cleaning and drying of grains were done separately for each treatment. Properly dried grain and straw were weighed and converted into $\mathrm{t} \mathrm{ha}^{-1}$ basis.

Data were collected on grain yield and different yield contributing components such as i. spike length $(\mathrm{cm})$, ii. number of spikelet spike ${ }^{1}$,iii.number of grain spike $^{-1}$, iv.1000-grain weight $(\mathrm{g}), \mathrm{v}$. grain yield $\left(\mathrm{t} \mathrm{ha}^{-1}\right)$, vi. straw yield $(\mathrm{t}$ $\left.\mathrm{ha}^{-1}\right)$, vii. biological yield $\left(\mathrm{t} \mathrm{ha}^{-1}\right)$, and viii. harvest index $(\%)$. Spike length was measured with a meter scale from the base to the tip of the spike of ten randomly selected spikes and the average value was recorded as spike length. Total number of spikelet's from ten randomly selected spikes from each plot was recorded and then averaged to have number of spikelet spike ${ }^{1}$.Ten spikes were selected and the total grains from total spike were recorded and averaged to number of grains spike ${ }^{-1}$. Thousand grains were counted from randomly selected samples of each plot and the weight (g) of grains was recorded after sun drying with an electrical balance. Grains from one square meter from each unit plot were dried and then weighed carefully. The results were expressed as $\mathrm{t} \mathrm{ha}^{-1}$ on $14 \%$ moisture basis. Like grain yield, oven dry weight of straw for one square meter of each plot was recorded and expressed as $\mathrm{t} \mathrm{ha}^{-1}$. Biological yield was calculated from the following formula:

Biological yield $\left(\mathrm{t} \mathrm{ha}^{-1}\right)=$ Grain yield $\left(\mathrm{t} \mathrm{ha}^{-1}\right)+$ Straw yield $\left(\mathrm{t} \mathrm{ha}^{-1}\right)$

Harvest index was calculated as the ration of economic yield (grain yield) to biological yield and expressed in terms of percentage. It was calculated by using the following formula (Donald, 1963)-

Harvest index $(\%)=\frac{\text { Grain yield }}{\text { Biological yield }} \times \mathbf{1 0 0}$

The collected data of each plot were statistically analyzed to obtain the level of significance using the computer based software MSTAT-C. Mean difference among the treatments were tested with the least significant difference (LSD) test at $5 \%$ level of significance.

\section{Results and Discussion}

\subsection{Effect of irrigation on yield and yield components of wheat}

Significant variation observed on spike lenght $(\mathrm{cm})$ by different irrigation treatments. The maximum spike length $(15.90 \mathrm{~cm})$ was found in irrigated condition (I) and the minimum spike length $(14.99 \mathrm{~cm})$ was observed in non irrigated condition $\left(\mathrm{I}_{0}\right)$ (Table 1). Pal and Upasani (2007) applied different irrigation treatments at same way and found significant effect on spike length. Statistically significant variation was observed on spikelets per spike in different irrigation treatments. The maximum spikelets spike ${ }^{-1}$ (18.92) was observed in irrigated condition (I) and and the lowest spikelets spike ${ }^{-1}(17.78)$ was 
observed in non irrigated condition $\left(\mathrm{I}_{0}\right)$ (Table 1). Irrigation has an effect on spikelets spike ${ }^{-1}$ also observed by Sarkar et al. (2010).

Different irrigation application showed statistically significant variation on grain spike ${ }^{1}$ of wheat (Table 1). The maximum grain spike ${ }^{-1}$ (56.58) was found from irrigated condition (I) and the minimum grain spike $^{-1}$ (52.72) was found from non irrigated condition $\left(\mathrm{I}_{0}\right)$. Sarkar et al. (2010) also observed that irrigation have a significant effect on grain spike ${ }^{-1}$.

Statistically significant variation was found by different irrigation application on 1000-grain weight $(\mathrm{g})$ of wheat (Table 1). The highest 1000grain weight (42.55) was recorded in irrigated condition (I) and the lowest 1000 -grain weight (39.15) was recorded in non irrigated condition $\left(\mathrm{I}_{0}\right)$. Similar results were observed by Ali and Amin (2004) and Sarkar et al. (2010).

Irrigation treatments showed statistically significant variation on yield $\left(\mathrm{t} \mathrm{ha}^{-1}\right)$ of wheat (Table 1). The maximum yield $\left(2.92 \mathrm{t} \mathrm{ha}^{-1}\right)$ was found from irrigated condition (I) and the lowest yield $\left(2.11 \mathrm{t} \mathrm{ha}^{-1}\right)$ was found from non irrigated condition $\left(\mathrm{I}_{0}\right)$. Sarkar et al. (2010) and Baser et al. (2004) reported that grain yield under nonirrigated conditions was reduced by approximately 40\%. Bazza et al. (1999) reported that one water application during the tillering stage allowed the yield to be lower only than that of the treatment with three irrigations but Meena et al. (1998) reported that wheat grain yield was the highest with 2 irrigations $(2.57$ ton/ha in 1993 and 2.64 ton/ha) at flowering and/or crown root initiation stages. Wheat is sown in November to ensure optimal crop growth and avoid high temperature at the grain development stage. Islam et al. (1993) reported that late planted wheat plants faced a period of high temperature stress during reproductive stages causing reduced kernel number spike ${ }^{-1}$ as well as the reduction of grain yield.

Significant variation was found in straw yield $(\mathrm{t}$ $\left.\mathrm{ha}^{-1}\right)$, biological yield $\left(\mathrm{t} \mathrm{ha}^{-1}\right)$ and harvest index
(\%) of wheatdue to application of irrigations (Table 1). The maximum straw yield $\left(5.37 \mathrm{t}^{\mathrm{h}}\right.$ $\left.{ }^{1}\right)$, biological yield $\left(8.21 \mathrm{t} \mathrm{ha}^{-1}\right)$ and harvest index (34.189\%) was recorded from irrigated condition (I) and the lowest straw yield $\left(4.488 \mathrm{t} \mathrm{ha}^{-1}\right)$, biological yield $\left(6.55 \mathrm{t} \mathrm{ha}^{-1}\right)$ and harvest index $\left(30.65 \mathrm{t} \mathrm{ha}^{-1}\right)$ was recorded from non irrigated condition $\left(\mathrm{I}_{0}\right)$.Similar results were found by Ali and Amin (2004) in their experiment.

\subsection{Effect of sowing dates on yield and yield components of wheat}

Spike length of wheat showed statistically significant variation due to different sowing dates (Table 2). The highest spike length (18.63 $\mathrm{cm})$ was observed from $S_{1}$ and the lowest spike length $(18.03 \mathrm{~cm})$ was recorded from $\mathrm{S}_{3}$. Chowdhury (2002) conducted an experiment with four sowing dates and reported that spike length decreased with delay in sowing.

Statistically significant variation observed on spikelets spike $^{-1}$ of wheat at different sowing dates. The maximum spikelets spike ${ }^{-1}(19.19)$ was found from $S_{1}$ which was statistically similar with the $S_{2}(18.89)$ and $3^{\text {rd }}$ sowing date $\left(S_{3}\right)$ given the lowest (16.99) (Table 2).

Different sowing date showed statistically significant variation on grain spike $^{-1}$ of wheat (Table 2). The maximum grain spike ${ }^{-1}$ (63.04) was recorded at $1^{\text {st }}$ sowing date $\left(\mathrm{S}_{1}\right)$ and the minimum grain spike $^{-1}$ (39.58) was recorded from $2^{\text {nd }}$ sowing date $\left(\mathrm{S}_{\mathbf{2}}\right)$. Similar observation found by Chowdhury (2002) who conducted an experiment with four sowing dates and reported that grains spike $^{-1}$ decreased with delay in sowing date from November 15 and the lowest grains spike ${ }^{-1}$ were recorded in December 15 sown plants.

Statistically significant variation observed on 1000-grain weight $(\mathrm{g})$ due to different sowing dates of wheat (Table 2). The maximum 1000 grain weight $(43.64 \mathrm{~g})$ was found from $1^{\text {st }}$ sowing date $\left(\mathrm{S}_{1}\right)$ and the lowest 1000 -grain weight $(38.02 \mathrm{~g})$ was found from $3^{\text {rd }}$ sowing date $\left(\mathrm{S}_{3}\right)$. 
Table 1. Effect of irrigation on spike length, spikelets spike ${ }^{-1}$, grain spike ${ }^{-1}, 1000$ - grain weight, grain yield, straw yield, biological yield and harvest index of wheat

\begin{tabular}{llllllccc}
\hline Irrigation & $\begin{array}{l}\text { Spike } \\
\text { lenght } \\
(\mathrm{cm})\end{array}$ & $\begin{array}{l}\text { Spikelets } \\
\text { spike }^{-1}\end{array}$ & $\begin{array}{l}\text { Grain } \\
\text { spike }^{-1}\end{array}$ & $\begin{array}{l}1000- \\
\text { grain } \\
\text { weight }(\mathrm{g})\end{array}$ & $\begin{array}{l}\text { Yield } \\
\left(\mathrm{t} \mathrm{ha}^{-1}\right)\end{array}$ & $\begin{array}{l}\text { Straw } \\
\text { yield } \\
\left(\mathrm{t} \mathrm{ha}^{-1}\right)\end{array}$ & $\begin{array}{c}\text { Biological } \\
\text { yield } \\
\left(\mathrm{t} \mathrm{ha}^{-1}\right)\end{array}$ & $\begin{array}{c}\text { Harvest } \\
\text { index } \\
(\%)\end{array}$ \\
\hline $\mathrm{I}$ & 15.90 & 18.92 & 56.58 & 42.54 & 2.91 & 5.37 & 8.20 & 34.18 \\
$\mathrm{I}_{0}$ & 14.99 & 17.78 & 52.72 & 39.15 & 2.11 & 4.47 & 6.54 & 30.65 \\
\hline LSD (0.05) & 0.175 & 0.279 & 0.843 & 0.83 & 0.128 & 0.149 & 0.230 & 1.248 \\
$\mathrm{CV}(\%)$ & 2.33 & 3.125 & 3.171 & 4.18 & 10.453 & 6.226 & 6.43 & 7.919 \\
\hline
\end{tabular}

Here: $\mathrm{I}=$ irrigation and $\mathrm{I}_{0}=$ no irrigation

Table 2. Effect of sowing dates on spike length, spikelets spike ${ }^{-1}$, grain spike ${ }^{-1}$, 1000- grain weight, grain yield, straw yield, biological yield and harvest index of wheat

\begin{tabular}{llllllccc}
\hline $\begin{array}{l}\text { Sowing } \\
\text { time }\end{array}$ & $\begin{array}{l}\text { Spike } \\
\text { lenght } \\
(\mathrm{cm})\end{array}$ & $\begin{array}{l}\text { Spikelets } \\
\text { spike }^{-1}\end{array}$ & $\begin{array}{l}\text { Grain } \\
\text { spike }^{-1}\end{array}$ & $\begin{array}{l}\text { 1000 grain } \\
\text { weight }(\mathrm{g})\end{array}$ & $\begin{array}{l}\text { Yield } \\
\left(\mathrm{t} \mathrm{ha}^{-1}\right)\end{array}$ & $\begin{array}{c}\text { Straw } \\
\text { yield } \\
\left(\mathrm{t} \mathrm{ha}^{-1}\right)\end{array}$ & $\begin{array}{c}\text { Biological } \\
\text { yield } \\
\left(\mathrm{t} \mathrm{ha}^{-1}\right)\end{array}$ & $\begin{array}{c}\text { Harvest } \\
\text { index } \\
(\%)\end{array}$ \\
\hline $\mathrm{S}_{\mathbf{1}}$ & 16.34 & 19.19 & 63.04 & 43.64 & 2.98 & 5.69 & 8.64 & 33.97 \\
$\mathrm{~S}_{\mathbf{2}}$ & 15.54 & 18.89 & 61.33 & 40.90 & 2.87 & 5.08 & 7.88 & 35.48 \\
$\mathrm{~S}_{3}$ & 14.47 & 16.99 & 39.58 & 38.02 & 1.68 & 3.99 & 5.60 & 27.81 \\
\hline $\mathrm{LSD}(0.05)$ & 0.3732 & 0.5321 & 3.202 & 1.523 & 0.2935 & 0.286 & 0.4370 & 3.193 \\
$\mathrm{CV}(\%)$ & 2.33 & 3.125 & 3.171 & 4.18 & 10.453 & 6.226 & 6.43 & 7.919 \\
\hline
\end{tabular}

Here: $S_{1}=1^{\text {st }}$ sowing, $S_{2}=2^{\text {nd }}$ sowing and $S_{3}=3^{\text {rd }}$ Sowing

Table 3. Interaction effect of irrigation and sowing date on straw yield $\left(\mathrm{t} \mathrm{ha}^{-1}\right)$, biological yield $\left(\mathrm{t} \mathrm{ha}^{-1}\right)$ and harvest index $(\%)$ of wheat

\begin{tabular}{lccc}
\hline Treatment & Straw yield $\left(\mathrm{t} \mathrm{ha}^{-1}\right)$ & Biological yield $\left(\mathrm{t} \mathrm{ha}^{-1}\right)$ & Harvest index $(\%)$ \\
\hline $\mathrm{IS}_{1}$ & $6.165 \mathrm{a}$ & $9.527 \mathrm{a}$ & $35.27 \mathrm{a}$ \\
$\mathrm{I}_{0} \mathrm{~S}_{1}$ & $5.220 \mathrm{c}$ & $7.757 \mathrm{c}$ & $32.68 \mathrm{bc}$ \\
$\mathrm{IS}_{2}$ & $5.498 \mathrm{~b}$ & $8.614 \mathrm{~b}$ & $36.14 \mathrm{a}$ \\
$\mathrm{I}_{0} \mathrm{~S}_{2}$ & $4.664 \mathrm{~d}$ & $7.156 \mathrm{~d}$ & $34.83 \mathrm{ab}$ \\
$\mathrm{IS}_{3}$ & $4.446 \mathrm{~d}$ & $6.483 \mathrm{e}$ & $31.16 \mathrm{c}$ \\
$\mathrm{I}_{0} \mathrm{~S}_{3}$ & $3.550 \mathrm{e}$ & $4.722 \mathrm{f}$ & $24.45 \mathrm{~d}$ \\
\hline $\mathrm{LSD}(0.05)$ & 0.2583 & 0.3997 & 2.163 \\
$\mathrm{CV}(\%)$ & 6.23 & 6.42 & 7.92 \\
\hline
\end{tabular}

Here: $S_{1}=1^{\text {st }}$ sowing, $S_{2}=2^{\text {nd }}$ sowing and $S_{3}=3^{\text {rd }}$ Sowing; $I=$ irrigation and $I_{0}=$ no irrigation 
Chowdhury (2002) conducted an experiment with four sowing dates and reported that 1000grain weight decreased with delay in sowing date from November 15 and the lowest 1000-grain weight were recorded in December 15 sown plants, and the results corroborated with that of (Rahman et al., 2009).

Different sowing date had a statistically significant variation on wheat yield $\left(\mathrm{t} \mathrm{ha}{ }^{-1}\right)$ (Table 2). The maximum yield $\left(2.98 \mathrm{t} \mathrm{ha}^{-1}\right)$ was found from $1^{\text {st }}$ sowing date $\left(\mathrm{S}_{1}\right)$ and the minimum yield $\left(1.69 \mathrm{t} \mathrm{ha}^{-1}\right)$ was found from $2^{\text {nd }}$ sowing date $\left(\mathrm{S}_{2}\right)$.

Thedates of sowing had a statistically significant effect on straw yield $\left(\mathrm{t} \mathrm{ha}^{-1}\right)$, biological yield ( $\mathrm{t}$ $\mathrm{ha}^{-1}$ ) and harvest index (\%) of wheat (Table 2). The maximum straw yield $\left(5.693 \mathrm{t} \mathrm{ha}^{-1}\right)$, biological yield $\left(8.642 \mathrm{t} \mathrm{ha}^{-1}\right)$ and harvest index $(35.48 \%)$ was found from $1^{\text {st }}$ sowing date $\left(\mathrm{S}_{1}\right)$, whilethe minimum straw yield $\left(3.998 \mathrm{t} \mathrm{ha}^{-1}\right)$, biological yield $\left(5.602 \mathrm{t} \mathrm{ha}^{-1}\right)$ and harvest index $(27.81 \%)$ was found from $3^{\text {rd }}$ sowing date $\left(\mathrm{S}_{3}\right)$.

\subsection{Interaction effect of irrigation and sowing date on yield and yield components of wheat}

Interaction effect of different irrigation level and sowing dates showed significant differences on spike length of wheat. Results showed that the maximum spike lenght was given at $\mathrm{IS}_{1}(17.08$ $\mathrm{cm})$ and the lowest was at $\mathrm{I}_{0} \mathrm{~S}_{3}(14.25 \mathrm{~cm})$ (Figure 1).

Interaction effect of different irrigations and sowing dates showed significant differences on spikelets spike ${ }^{-1}$ of wheat. Results showed that the maximum spikelets spike ${ }^{-1}$ was given at IS $_{1}$ (20.03) and the lowest spikelets spike $^{-1}$ was observed at $\mathrm{I}_{0} \mathrm{~S}_{3}$ (16.58) (Figure 2).

Interaction effect of different levels of irrigation and sowing date showed significant differences on grain spike ${ }^{-1}$ of wheat. Results showed that the maximum grain spike $^{-1}$ was given by the treatment $\mathrm{IS}_{1}(65.58)$ and the lowest grain spike ${ }^{-1}$ was observed with $\mathrm{I}_{0} \mathrm{~S}_{3}$ (37.97) (Figure 3).

Interaction effects of sowing dates and irrigations showed significant differences on 1000-grain weight (g) of wheat. Results showed that the maximum 1000-grain weight $(\mathrm{g})$ was observed with $\mathrm{IS}_{1}$ (44.92) and lowest (36.37) was in the treatment $\mathrm{I}_{0} \mathrm{~S}_{3}$ (Figure 4).

Interaction effect of different irrigations and sowing dates showed significant differences on yield $\left(\mathrm{t} \mathrm{ha}^{-1}\right)$ of wheat. Results showed that the maximum yield $\left(\mathrm{t} \mathrm{ha}^{-1}\right)$ was given by $\mathrm{S}_{1} \mathrm{I}(3.387)$ and the lowest yield $\left(\mathrm{t} \mathrm{ha}^{-1}\right)$ was observed in the treatment $\mathrm{S}_{3} \mathrm{I}_{0}(1.189)$ (Figure 5).

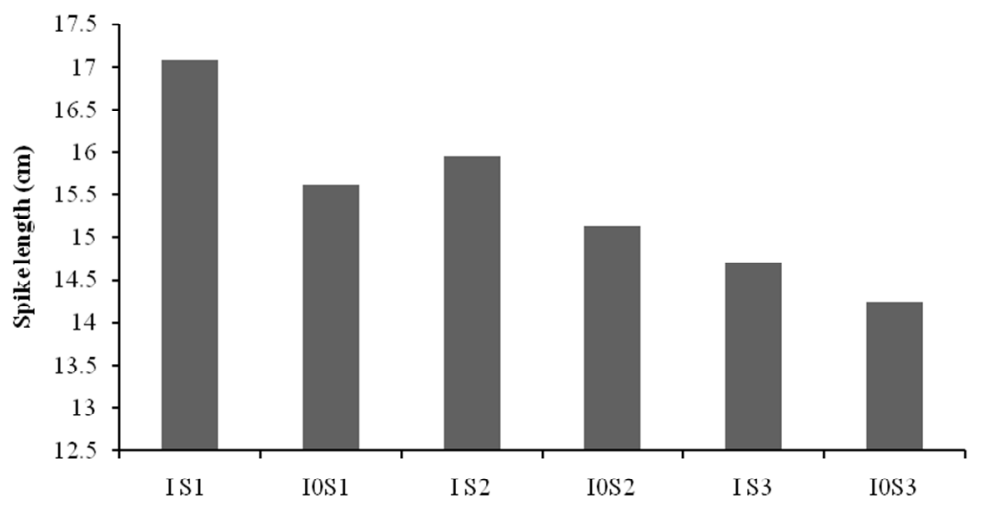

Here: $S_{1}=$ Nov. 18 sowing, $S_{2}=$ Dec. 03 sowing and $S_{3}=$ Dec. 19 Sowing; $I=$ irrigation and $\mathrm{I}_{0}=$ no irrigation. $\left(\mathrm{LSD}_{0.05}=0.3038\right)$

Figure 1. Interaction effect of irrigation and sowing date on spike length $(\mathrm{cm})$ of wheat 


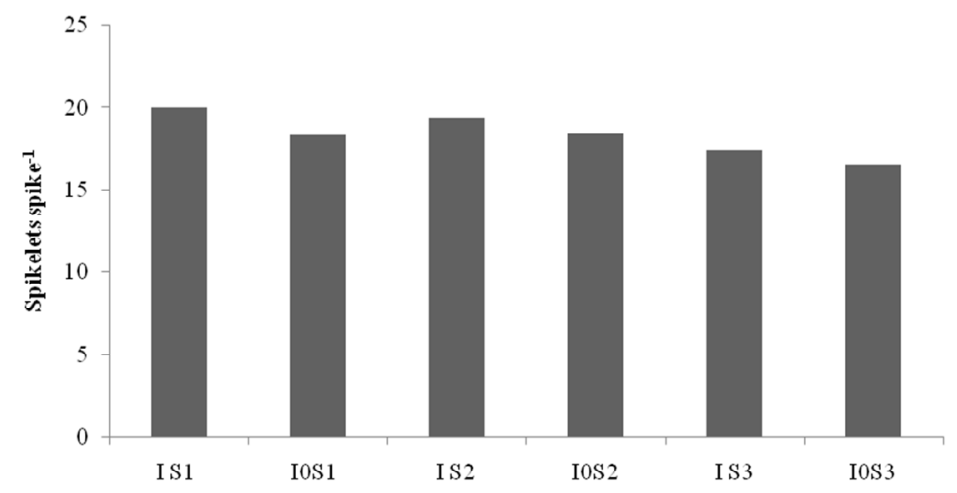

Figure 2. Interaction effect of irrigation and sowing date on spikelets spike ${ }^{-1}$ of wheat

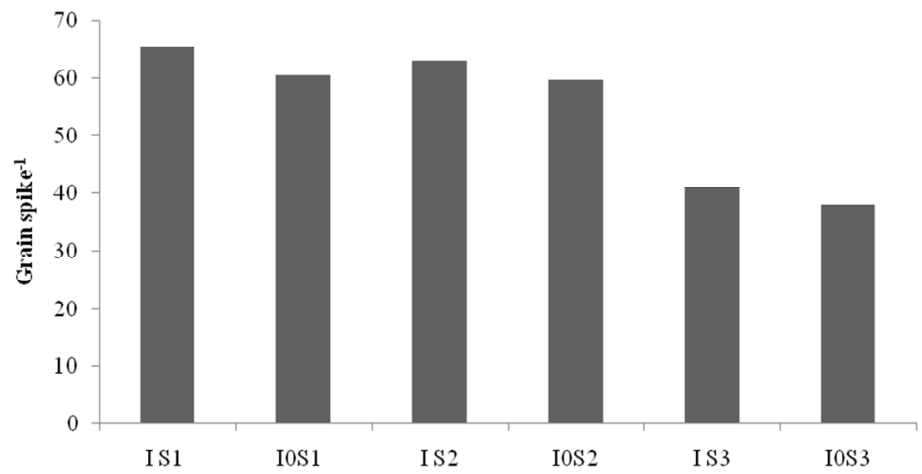

Figure 3. Interaction effect of irrigation and sowing date on grain $\operatorname{spike}^{-1}$ of wheat

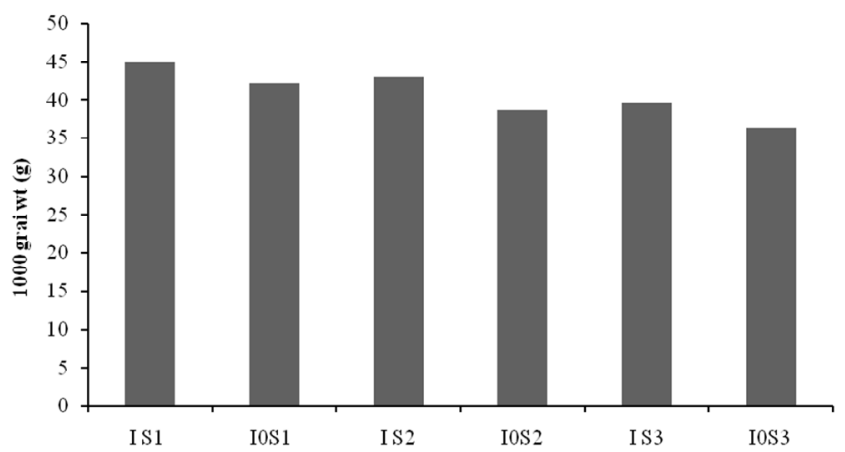

Figure 4. Interaction effect of irrigation and sowing date on 1000-grain weight (g) of wheat

Here: $S_{1}=$ Nov. 18 sowing, $S_{2}=$ Dec. 03 sowing and $S_{3}=$ Dec. 19 Sowing; $I=$ irrigation and $I_{0}=$ no irrigation. $\left(\mathrm{LSD}_{0.05}=1.438\right)$ 


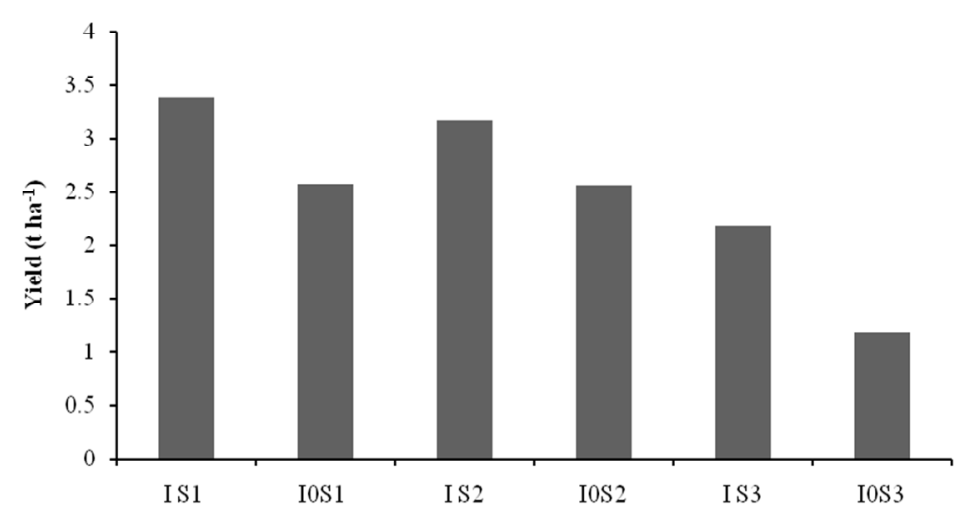

Here: $S_{1}=$ Nov. 18 sowing, $S_{2}=$ Dec. 03 sowing and $S_{3}=$ Dec. 19 Sowing; $I=$ irrigation and $\mathrm{I}_{0}=$ no irrigation. $\left(\mathrm{LSD}_{0.05}=0.2213\right.$ )

Figure 5. Interaction effect of irrigation and sowing date on yield $\left(\mathrm{t} \mathrm{ha}^{-1}\right)$ of wheat

Interaction effect of different levels of irrigation and sowing date showed significant differences on straw yield $\left(\mathrm{t} \mathrm{ha}^{-1}\right)$ of wheat. The maximum straw yield (6.165 $\left.\mathrm{t} \mathrm{ha}^{-1}\right)$, biological yield $(9.527$ $\left.\mathrm{t} \mathrm{ha}^{-1}\right)$ and harvest index $(36.14 \%)$ was found from $\mathrm{IS}_{1}$. On the other hand the lowest straw yield $\left(3.550 \mathrm{t} \mathrm{ha}^{-1}\right)$, biological yield $\left(4.722 \mathrm{t} \mathrm{ha}^{-1}\right)$ and harvest index $(31.16 \%)$ was found from $\mathrm{I}_{0} \mathrm{~S}_{3}$ (Table 3).

\section{Conclusions}

Sowing date and irrigation played a vital role for the growth and yield of wheat. Different sowing dates and irrigation treatments showed significant difference on yield and yield contributing characters of wheat plant. Interaction effect of different sowing dates and irrigation treatments also showed the significant variation on yield contributing characters. Wheat yield was found the maximum when sown on 18 November and irrigated three times at different growth stages.

\section{References}

Acevedo, E., Nachit, M. and Ferrana, G. O. 1991. Effects of heat stress on wheat and possible selection tools for use in breeding for tolerance. In: D. A. Saunders (ed.)
Wheat for the Non-traditional Warm Areas. CIMMYT. Mexico D. F. 401-420 pp.

Al-Khatib, K. and Paulsen. G. M. 1990. Photosynthesis and productivity during high-temperature stress of wheat genotypes from major world regions. Crop Science. 30:1127-1132.

Ali, A. and Amin, S. 2004. Effect of irrigation frequencies on yield attributes of wheat cultivar (Triticum astivum, Shatabdi). Journal of Food Technology. 2(3): 145147.

Badruddin, M., Sauders, D. A., Siddique, A. B., Hossain, M. A., Ahmed, M. O., Rahman, M. M. and Parveen, S. 1994. Determining Yield Constraints for Wheat Production in Bangladesh. 265-271 pp.

BARI. 1997. Increase wheat cultivation and decrease irrigation cost (A folder in Bengali). Wheat Res. Centre. Bangladesh Agril. Res. Inst. Nashipur, Dinajpur. 12$15 \mathrm{pp}$.

Baser, I., Sehirali, S., Orta, H., Erdem, T., Erdem, Y. and Yorganclar, O. 2004. Effect of different water stresses on the yield and yield components of winter 
wheat. Cereal Research Communications. 32(2): 217-223.

Bazza, M. J., Sadaria, S. G., Patel, J. C. 1999. Wheat and sugar beet with irrigation management practices through waterdeficit irrigation. The Indian Journal of Agricultural Sciences, 69(13): 431-435.

BBS. 2008. Statistical Year Book of Bangladesh. Bangladesh Bureau of Statistics. Statistics Division. Government of the Peoples Republic of Bangladesh. Dhaka.p. 121.

BBS. 2011. Monthly Statistical Bulletin, Bangladesh. Statistics Division. Ministry of Planning. Government of the Peoples Republic of Bangladesh. Dhaka. p. 72.

Chowdhury, M. Z. R. 2002. Effect of different sowing dates on morphopysiological features, yield and yield contributing characters of three modern wheat varieties. M.S. thesis, Department of crop botany, HSTU, Dinajpur.

Dubin, Y. P. and Ginkel, P. M. 1991. Wheat cultivation in the warmer climates exists in the South-East Asia including Bangladesh. The Indian Journal of Agricultural Sciences. 58(1): 131-135.

FAO. 2000. Production Year Book. Food and Agricultural of the United Nations, Rome, Italy. 54: 176-186.

Islam, N., Ahmed, S. M., Razzaque, M. A.,Sufian, A. and Hossain, M. A. 1993. A study on the effect of seeding dates on the yield of wheat varieties. Bangladesh Journal of Agricultural Research. 18(1): 102-107.

Khajanij, S. N. and Swivedi, R. K. 1988. Response of wheat (Triticum aestivum L.) to irrigation and fertilizer mixture under late condition. Bhartiya Krishi Anusandhan Patrika. 3(1): 37-42.

Khakwani, A. A., Dennett, M. D., Munir, M. and Abid, M. 2012. Growth and yield response of wheat genotypes to water stress at booting and anthesis stages of development. Pakistan Journal of Botany. 44: 879-886.

Khan, M. I., Tila, M., Subhan, F., Amin, M. and Shah, S. T. 2007. Agronomic evaluation of different bread wheat (Triticum aestivum L.) genotypes for terminal heat stress. . Pakistan Journal of Botany. 39(7): 2415-2425.

Meena, B. S., Gautam, R. C. and Kaushik, S. K. 1998. Pearl millet (Pennlsetum glaucum) and wheat (Triticum aestivum) cropping sequence as influenced by cultural, nutritional and irrigation factors under limited moisture conditions. The Indian Journal of Agricultural Sciences. 68(10): 638-643.

Murungu, F. S. and Madanzi, T. 2010. Seed priming, genotype and sowing date effects on emergence, growth and yield in a tropical low altitude area of Zimbabwe. African Journal of Agricultural Research. 5(17): 2341-2349.

Pal, S. K. and Upasani, R. R. 2007. Grain growth and yield of late sown wheat under different irrigation schedule, Ranchi, India. Birsa Agricultural University. Journal of Researh Birsa Agricultural University. 14(2): 187-192.

Rahman, M. M., Hossain, A., Hakim, M. A., Kabir, M. R. and Shah. M. M. R. 2009. Performance of wheat genotypes under optimum and late sowing condition. International Journal of Sustainable Crop Production. 4(6): 34-39.

Sarkar, P. K., Islam, M. S., Biswas, S. K., Hossain, M. A. and Hasan, S. 2010. Validation of dras model for irrigation of wheat. Bangladesh. Journal of Agricultural Research. 35(3):403-4011.

Yajam, S. and Madani, H. 2013. Delay sowing date and its effect on Iranian winter wheat cultivars yield and yield components. Annals of Biological Research. 4(6): 270275. 